\title{
Passing of a giant: Genie Clark (4 May 1922-25 February 2015)
}

\author{
David L. G. Noakes
}

Published online: 15 September 2015

C) Springer Science+Business Media Dordrecht 2015

Whale shark (Rhincodon typus) at the Okinawa Churaumi Aquarium, Japan. Copies of her books and a personal note from Genie are key features of the informational display about sharks at the Aquarium. (photo by David L. G. Noakes)

Sometime no words are possible, sometimes no words are necessary.

As I completed the final edits on the obituary for Rosemary Lowe-McConnell (Stiassny 2015) the notice of Genie's death flashed on my computer screen. No words are necessary for readers of this journal to describe Genie and her contributions to subjects as diverse as simultaneous hermaphroditism in serranids, instrumental conditioning in sharks, courtship in poeciliids, live-bearing in whale sharks and shark repellants in flatfish (Clark 1959a, 1959b, Clark et al 1948, Clark \& George 1979, Joung et al. 1996). Genie was one of the first Advisory Editors and a major contributor for this journal. Genie, Ro and ET were the focal individuals for our dedicated issue on women in ichthyology (Balon et al. 1994), and her achievements are presented there in some detail. Of course we must recognize that her scientific career continued for another 20 years after that recognition! Books, films, videos and electronic sources document her remarkable career and scientific achievements. It is also worth noting Genie's extraordinary kindness, generosity and support to students of every age, her boundless enthusiasm displayed on the pages of National Geographic and her total devotion to her science. Remarkable among scientists for her ability to communicate her enthusiasm and knowledge to the general public, she was quite rightly recognized as "The Shark Lady" by everyone.

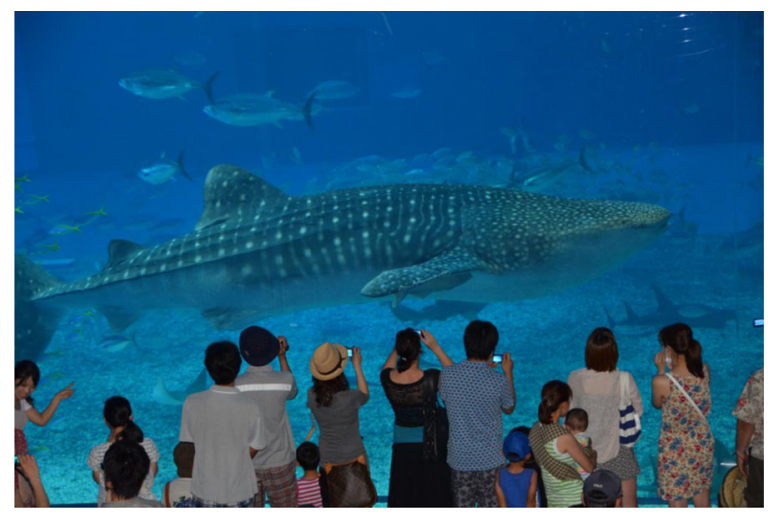

D. L. G. Noakes $(\bowtie)$

Fisheries and Wildlife Department and Oregon Hatchery

Research Center, Oregon State University,

104 Nash Hall, Corvallis, OR 97331-3803, USA

e-mail: david.noakes@oregonstate.edu 


\section{References}

Balon EK, Bruton MN, Noakes DLG (1994) Women in ichthyology: an anthology in honour of ET, Ro, and Genie. Kluwer Academic, Doredrecht, p. 456

Clark E (1959a) Functional hermaphroditism and self-fertilization in a serranid fish. Science 129:215216

Clark E (1959b) Instrumental conditioning of lemon sharks. Science 130:217-218
Clark E, LR, Gordon M (1948) An analysis of the sexual behavior of two sympatric species of poeciliid fishes and their laboratory induced hybrids. Anat Rec 101:692-722

Clark E, George A (1979) Toxic soles, Pardachirus marmoratus from the Red Sea and P. pavoninus from Japan, with notes on other species. Environ Biol Fish 4:103-123

Joung SJ, Chen CT, Clark E, Uchida S, Huang WY (1996) The whale shark, Rhincodon typus, is a livebearer: 300 embryos found in one 'megamamma' supreme. Environ Biol Fish 46:219-223

Stiassny MJ (2015) Rosemary Lowe-McConnell, obituary. Environ Biol Fish 98:1719-1722 